\title{
Food Budget Shares and Elasticities in Malawi's Prisons
}

\author{
Hastings B. Moloko ${ }^{1}$, Davis H. Ng'ong'ola ${ }^{2}$ Joseph Dzanja $^{2} \&$ Thabie Chilongo ${ }^{2}$ \\ ${ }^{1}$ University of Malawi, Malawi \\ ${ }^{2}$ Lilongwe University of Agriculture and Natural Resources, Malawi \\ Correspondence: Hastings B. Moloko, University of Malawi, Malawi. Tel: 265-888-843-209. E-mail: \\ hmoloko@poly.ac.mw
}

Received: June 22, 2017 Accepted: August 15, 2017 Online Published: January 4, 2018

doi:10.5539/sar.v7n1p109 URL: https://doi.org/10.5539/sar.v7n1p109

\begin{abstract}
While Malawi's per capita cereal production may be higher than her per capita cereal consumption, Malawi is a net cereal importer and thus food insecure. The food situation is much worse in Malawi's prisons because inmates generally eat one meal per day.

The general objective of this study was to determine food budget shares and elasticities for the food stuffs commonly eaten in Malawi's prisons. Using structured questionnaires in face to face interviews, the study collected data from 1000 prisoners and 30 officers-in-charge from all prisons in the country. The data was analysed using Stata 12 and employed the quadratic almost ideal demand system (QUAIDS) model as an analytical tool.

Results from the analysis showed that budget shares for maize and beans were high as reflected by the fact that 86.5 per cent of the prison food budget was spent on these two food items while 6.8 per cent was spent on meat and vegetables. Maize was inelastic while meat, beans and salt were elastic with the own-price elasticity for meat being the highest. Expenditure elasticities for maize, meat and beans, at above unity, showed that these food items were luxuries in Malawi's prisons.
\end{abstract}

Keywords: Malawi's prisons, budget shares, own-price elasticity, cross-price elasticity, expenditure elasticity

\section{Introduction}

The introduction gives a brief narrative about Malawi's prisons, states the problem and makes a justification for the study. Study objectives are then given and finally, study limitations are presented.

Politically, Malawi is divided into four regions, these being the Northern, the Central, the Eastern and the Southern regions. There are six prisons with a prisoner population of 1,717 in the Northern region. In the Central region, there are eight prisons with a prisoner population of 3,784. The Eastern region has eight prisons with 4,072 prisoners, while the Southern region has 3,025 prisoners in eight prisons. There were thus 12,598 prisoners in Malawi's 30 prisons in 2016 when this study was conducted.

Statement of the Problem: Although Malawi is generally food insecure, it is common in Malawi that most people consume three meals per day. What differs is mainly the quality, quantity and variety of the food that they eat. Inmates in Malawi's prisons, however, generally eat one meal per day (African Commission on Human and Peoples' Rights, 2002; Penal Reform International 2005). These reports mention food issues as observations made in relation to health and human rights. None of these reports is specifically about prison food budget shares or price elasticities or expenditure elasticities of foods commonly eaten in Malawi's prisons. The fact that no report nor study delineated these economic aspects of food items commonly eaten in Malawi's prisons became a problem that this study intended to address.

Justification of the Study: The Malawi Government's overall objective of the Food and Nutrition Security Policy is to significantly improve the food and nutrition security of the Malawi population (Malawi Government, 2005) while the specific objective of the Food Security Policy, is to guarantee that all men, women and youth in Malawi have, at all times, physical and economic access to sufficient nutritious food required to lead a healthy and active life (Malawi Government, 2006). Since prisons accommodate about 0.08 percent of the Malawi population, it is important that prisons are food secure and that every prisoner has access to not less than the minimum meal requirement. It was important that this study be carried out so that prison food budget shares, 
price elasticities and expenditure elasticities of foods commonly eaten in Malawi's prisons could be delineated in order to lay the foundation upon which efforts to improve and re-engineer the food situation in Malawi's prisons could be based. This would enable policy makers and prison management to take appropriate policy and budgetary measures regarding prison subvention, strategic resource allocation, and food production or procurement to accurately address the problem and improve prison food security. Also, since no study had been conducted in this area, it was important to conduct this study so that the existing knowledge gap could be filled.

Objectives of the Study: The general objective of this study was to determine the food budget shares and elasticities for the food stuffs commonly eaten in Malawi's prisons. The specific objectives were:

i. To determine the food budget shares for the foods commonly eaten in Malawi's prisons, and

ii. To determine the price and expenditure elasticities for the foods commonly eaten in Malawi's prisons.

Limitations of the Study: There were two major limitations to the study. The first was that all interviewees were male. This was because, for security reasons, the research team was only allowed access to prisoners that committed less serious offenses. Such prisoners were allowed to go out for farming activities because they were considered a lower security risk. The research team was advised to interview the sampled ones as they carried out their farming chores. No female prisoners were in this category, not necessarily because they committed serious crimes, but because female prisoners were not allowed to go out for farming duties and the research team was not allowed to enter into the female side of the prison.

The second limitation was that only 1000 prisoners, instead of the required 1418 prisoners were interviewed. This was because some of the prisoners that were selected for interviewing, according to the random sampling method used in the study, were males that were not allowed to go out of confinement because of the nature of their crimes or females, who the research team was not allowed to meet. The research team was not permitted to follow prisoners to their cells.

The food situation in Malawi: The Millennium Development Goals (MDGs) through the medium term development strategy, the Malawi Growth and Development Strategy (MGDS), identified nine key priority development goals (Malawi Government, 2010). The first of these development goals is to eradicate extreme poverty and hunger. To achieve this, the Government's target was to halve, between 1990 and 2015, the proportion of people who suffered from hunger. One of the indicators for monitoring hunger was the proportion of the population living below the minimum level of dietary energy consumption of 2,100 kilocalories per person per day (Ecker \& Qaim, 2008; Malawi Government, 1999).

Malawi is an aggregate net exporter of food. The bulk of the food exports, however, are non-cereals such as tea and sugar and so although the country is a net food exporter, it remains a net importer of cereals and thus food insecure. Maize is the staple food in Malawi (Kidane, et al., 2006; FAO, 2010; World Bank, 2008; FAO, 2015; De Graaff, 1985; IFPRI, 2012).

The food situation in Malawi's prisons: It is a requirement of the United Nations that every prisoner should be provided, by the administration at the usual hours, with food of nutritional value adequate for health and strength, of wholesome quality and well prepared and served (Medecins Sans Frontieres, 2009). The Malawi Prison Act Cap. 9:02, (1983) provides a dietary schedule for prisoners belonging to various categories of prisons. Despite these legally binding dietary guidelines, the practice on the ground is different. The African Commission on Human and Peoples' Rights ( 2002) observed that Malawian prisoners receive only one meal per day and that meals are not balanced as prisoners eat the same food every day. The report also observed that the meals comprise of maize (nsima) and boiled beans and sometimes pigeon peas or vegetables. It further observed that almost no meat nor fish is provided, but that salt is available in all prisons. This is a typical case of food insecurity.

\section{Materials and Methods}

Data Collection Techniques: Both primary and secondary data were collected using questionnaires, one administered to prisoners, and the other to prison officers-in-charge. These questionnaires were administered by interviewers on face to face basis. Secondary data were collected from official records obtained from the Malawi Prison Service Headquarters and the various prisons that were visited.

Data Analysis: Data were entered in Excel and analysed using Stata 12. The output from the analysis was reported using descriptive statistics such as means, proportions and percentages.

Sampling Methods: All prisons in Malawi formed the field of study and every inmate, except those that had been in prison for less than four weeks, was an eligible interviewee. The four week requirement is a normal procedure followed by the USAID-funded Food and Nutrition Technical Assistance (FANTA) project which 
developed a questionnaire (Swindale \& Bilinsky, 2006; Maxwel \& Frankenberger, 1992) upon which the questionnaires used in this study were based. In order to select respondents from the population of inmates, the stratified random sampling and simple random sampling methods were used. The stratified random sampling method was applied to select $n$ units out of $N$ sub-populations called strata. In this case, each prison was a strata and from each strata $n$ number of inmates were selected using simple random sampling in order to give each prisoner an equal chance of being selected (Agresti, 1996; Zikmund, 1997; McGill et al., 2000; Bryars, 1983). In order to select participating inmates, tables of random numbers (Magnani, 1997) were used. In selecting prison officers for the interview, the purposive sampling method was used.

Sample Size: For more precision on sample size calculation, when population size and population proportions are known, the formula given below is used (Kothari, 2004).

$$
n=\frac{z^{2}}{e^{2}} \frac{p \cdot q \cdot N}{(N-1)+z^{2} \cdot p \cdot q}
$$

where $n=$ sample size, $z=1.96=$ z-value yielding $95 \%$ confidence level, $p=$ proportion of the population of interest, $q=1-p, N=12,598=$ the population of interest, $e=5 \%=$ absolute error in estimating $p$.

The population proportion for each prison was calculated as in Equation (2).

Prison proportion,

$$
p=\frac{\text { Number of prisoners at a given prison }}{\text { Total prisoner population in Malawi }}
$$

In 2016, the total number of, both convicted and un-convicted, inmates in Malawi's prisons was 12,598 (Malawi Government, 2016), while the population of Malawi as given by the UNDP in its 2011 Human Development Report was 15,380,900 (UNDP, 2011). Following the reasoning articulated above and applying Equation (1), the value of $n$, the sample size, was found to be 1418 . However, when conducting the survey, only 1,000 inmates were interviewed because of the study limitations.

Data were collected by three trained interviewers using a questionnaire that had been reviewed by a group of key informants, refined by eight prisoners that were representative of the survey population but who were not part of the survey sample, and pretested on fifteen prisoners through a preliminary survey. Data collected were subjected to regression and correlation analysis and results summarized.

Model Specification. The quadratic almost ideal demand system (QUAIDS) model was used to address the objective of the study.

\section{The Quadratic Almost Ideal Demand System model}

To compute food budget shares in the past, use had been made of the almost ideal demand system (AIDS) of Deaton and Muellbauer which had been a popular functional form to model demand behaviour during the past two decades. The AIDS model had budget shares that were linear functions of log total expenditure. AIDS is a member of the Price-Independent Generalized Logarithmic (PIGLOG) class of demand models (Sola, 2013) which are derived from indirect utility functions that are themselves linear in log total expenditure. However, there was a growing body of literature providing evidence on the importance of allowing for nonlinearity in the budget share equations (Pangaribowo \& Tsegai, 2011).

The quadratic almost ideal demand system (QUAIDS) model, which has budget shares that are quadratic in log total expenditure, is an example of the empirical demand systems that have been developed to allow for this expenditure nonlinearity (Banks, et al., 1997). The model is also quadratic in expenditure if we assume that there is a non-linear relationship between income and expenditure.

Many studies confirm the appropriateness of QUAIDS in modeling preferences. For example, Abdulai (2002) used the QUAIDS model to analyze food expenditure data from Switzerland. Moro and Sckokai (2000) used it on Italian food expenditure data, and Blundell and Robin (1999) applied it on UK expenditure data for consumption goods. Furthermore, Fisher et al. (2001) applied the QUAIDS model to study the US consumption data, Abdulai and Aubert (2004) used it on Tanzanian food expenditure data, Meenkashi and Ray (1999) on Indian food expenditure data, Gould and Villarreal (2006) on Chinese food expenditure data, and Molina and Gil (2005) applied it on consumption data from Peru. 
The QUAIDS model is a generalization of PIGLOG preferences based on the following indirect utility (V) function:

$$
\ln V=\left\{\left[\frac{\ln m-\ln a(p)}{b(p)}\right]^{-1}+\lambda(p)\right\}^{-1}
$$

where $\mathrm{m}$ is the total food or food group expenditure, and $\mathrm{p}$ is a vector of food prices. The term $\frac{\ln m-\ln a(p)}{b(p)}$ is the indirect utility function of a demand system of the (PIGLOG) preference class. The functions $\ln a(p)$ and $b(p)$ are the translog and the Cobb-Douglas price aggregator functions defined by:

$$
\ln a(p)=\alpha_{0}+\sum_{i=1}^{n} \alpha_{i} \ln p_{i}+\frac{1}{2} \sum_{i=1}^{n} \sum_{i=1}^{n} \gamma_{i j} \ln p_{i} \ln p_{j}
$$

And

$$
\mathrm{b}(\mathrm{p})=\prod_{i=1}^{n} p_{i}^{\beta_{i}}
$$

The price aggregator function $\lambda(p)$ is given by

$$
\lambda(p)=\sum_{i=0}^{n} \lambda_{i} \ln p_{i}
$$

Applying Roy's identity, after appropriate substitutions to equation (3), food budget shares for each food group can be expressed as:

$$
w_{i}=\alpha_{i}+\sum_{j=1}^{n} \gamma_{i j} \ln p_{j}+\beta_{i} \ln \left(\frac{m}{a(p)}\right)+\frac{\lambda_{i}}{b(p)}\left(\ln \left(\frac{m}{a(p)}\right)\right)^{2}, \forall_{i}=1, \ldots, n
$$

The theoretical restrictions of adding-up, homogeneity, and Slutsky symmetry are imposed in the basic QUAIDS by setting

$$
\begin{gathered}
\sum_{i=1}^{n} \alpha_{i}=1, \quad \sum_{i=1}^{n} \beta_{i}=0, \sum_{i=1}^{n} \lambda_{i}=0, \sum_{j=1}^{n} \gamma_{i j}=0, \quad \forall_{i}=1, \ldots \ldots n, \\
\sum_{i=1}^{n} \gamma_{i j}=0, \quad \forall_{j}=1, \ldots ., n, \quad \text { and } \quad \gamma_{i j}=\gamma_{j i}, \quad \forall_{i} \neq j
\end{gathered}
$$

From equation (7), it can be seen that the QUAIDS collapses to the AIDS when all $\lambda i$ equal zero. In conformity with the first budgeting stage, linear socioeconomic translation was allowed for through the intercept in equation (7).

This study applied a two-stage budgeting process on prison food following Blundell et al. (1993), who used the two-stage budgeting process in demand elasticity estimations in the fish industry, while Dey (2000) and Kumar (2004) used it for Bangladesh and India respectively. The approach worked on the premise that in the first stage, the prison made decisions on how much of its subvention was to be allocated to food given that some of the subvention needed to cater for other non-food goods. The model further assumed that in the second stage, the prison allocated the total food expenditure among the different food items that prisoners ate (Kumar et al, 2011; Tafere \& Worku, 2012; Torero \& Robles, 2008; Mittal, 2010). Below are the specific functional forms used in the two stages:

\section{Stage 1: The food expenditure function}

$$
L_{n}(M)=\alpha+y_{1} L_{n}\left(P_{f}\right)+y_{2} L_{n}\left(P_{n f}\right)+\beta_{0} L_{n}(Y)+\beta_{1}\left(L_{n} Y\right)^{2}
$$

where $M$ is individual prison food expenditure; $Y$ is individual prison total expenditure (subvention); $P_{f}$ is individual prison specific price index for food; $P_{n f}$ is the non-food price index. Equation (9) was estimated by the OLS method, and homogeneity of degree zero in prices and income was imposed by restricting

$$
Y_{1}+Y_{2}+\beta_{0}+2 \beta_{1} L_{n}(Y)=0 \text { at the sample mean of } L_{n}(Y)
$$

Mittal (2010) and, Deaton and Muellbauer (1980) suggested approximating the price index P by the Stone geometric price index. 


$$
l_{n} P^{*}=\sum_{i} w_{i} l_{n} p_{i}
$$

\section{Stage 2: The QUAIDS model}

In stage 2, the QUAIDS model was used. The specific functional form for the $i^{\text {th }}$ food item was:

$$
S_{i}=a_{i}+\sum_{j} b_{i j} L_{n}\left(F P_{i}\right)+c_{1 i}\left(L_{n} \frac{M}{I}\right)^{2}+\sum_{k} e_{i k} I M R_{k}
$$

Where $F P_{i}$ is price of the $i^{\text {th }}$ food item; $I$ is Stone geometric price index. The parameters $a_{i}, b_{i j}, c_{i}$, and $e_{i k}$ are estimated by imposing the homogeneity (degree zero in prices), symmetry (cross price effects are same across the foods) restrictions. The following restrictions are econometrically imposed.

Homogeneity: $\sum_{j=1}^{n} b_{i j}=0$; Symmetry: $b_{i j}=b_{j i}, \frac{c_{11}}{c_{10}}=\frac{c_{21}}{c_{20}}=\cdots=\frac{c_{n 1}}{c_{n 0}}$

The homogeneity and symmetry restrictions are imposed at sample mean. Because of the quadratic specification of the demand system (Equations 9 and 12), Mittal (2010) citing Blundell et al. 1993 said that a test of symmetry, in addition to the normal requirements, required that the ratio of the coefficients on the food expenditure and the square terms in food expenditure be the same for all food items. The predicted value of food expenditure obtained from stage 1 was used as the explanatory variable in stage 2 . The expenditure and price elasticities became:

Food expenditure elasticity:

$$
\eta_{i}=\left[c_{i 0}+\frac{2 c_{i 1} L_{n}(F)}{w_{i}}\right]+1
$$

Uncompensated price elasticity:

$$
\xi_{i j}=\left\{\frac{b_{i j}}{w_{i}}\right\}-\left[c_{i 0}+2 c_{i 0} L_{n}(F)\right]\left\{\frac{w_{j}}{w_{i}}\right\}-k_{i j}
$$

where $k_{i j}$ is Kronecker delta, which takes the value of one for own-price elasticity and zero for cross-price elasticity; and $w_{i}$ is the budget share of the $i^{\text {th }}$ food item used as a weight in constructing Stone's price index.

After the expenditure and uncompensated price elasticities are estimated, the compensated own and cross-price elasticities are calculated, using Slutsky equation in elasticity form, as:

$$
\xi_{i j}^{H}=\xi_{i j}+w_{j} \eta_{i}
$$

where $\xi_{i j}^{H}$ is the compensated (Hicksian) price elasticity.

Income elasticity of demand for an individual food item, $\eta_{i}^{y}$, is estimated as the product of expenditure elasticity of the individual food item, $\eta_{i}$, and food expenditure elasticity with respect to total income, $\eta^{y}$, where $\eta_{i}^{y}=\eta_{i} * \eta^{y}$.

The own price elasticity of demand is a measure of the proportionate change in quantity demanded in response to a proportionate change in a good's own price and, normally, carries a negative sign except in the case of a giffen good when it carries a positive sign. A giffen good is an inferior good whose demand, paradoxically, moves in the same direction as its price; for example, its demand increases as its price increases (Huang \& David, 1993). The income or expenditure elasticity of demand is a measure of the proportionate change in quantity demanded in response to a proportionate change in income. The cross-price elasticity of demand is a measure of the proportionate change in quantity demanded of some good, $x$, in response to a proportionate change in the price of some other good, $y$ (Tefera, Demeke, \& Rashid, 2012). Positive cross-price elasticities show substitutability while negative cross-price elasticities indicate complementarity effects (Snyder and Nicholson, 2008).

\section{Results and Discussion}

Prison Food Budget Shares. Foods that were rarely consumed, such as, cooking oil, fruits and sugar, were not included in the analysis as their consumption was negligible and were eaten in only a few prisons on isolated occasions. Maize, in the form of nsima (a thick porridge made from maize flour), was eaten with beans almost every day in all prisons in the country. Consequently, maize took 52.2 percent of the prison food budget while beans took 34.3 percent. Thus, 86.5 percent of the prison food budget was spent on maize and beans. Using household data, Ecker and Qaim (2008) studying the income and price elasticities of food demand and nutrient consumption in Malawi found that the weighted mean budget share for starchy foods was 45.9 percent and that 
maize took 72.1 percent of the starchy foods budget. They also found that the weighted mean budget share for pulses was 9.6 percent and that 37.0 percent of the budget for pulses was taken by beans. Their results, especially those for beans, compare well with those found in this study as shown in Table 1.

Table 1. Prison food budget shares in percentages

\begin{tabular}{lccc}
\hline Variable & N & Mean Share (\%) & Std. Dev. \\
\hline Wmaize & 30 & 52.2 & 0.120 \\
Wmeat & 30 & 2.0 & 0.035 \\
Wbean & 30 & 34.3 & 0.094 \\
Wvege & 30 & 4.8 & 0.127 \\
Wsalt & 30 & 6.7 & 0.069 \\
\hline
\end{tabular}

Vegetables, which took 4.8 percent of the budget, were eaten occasionally while meat, on which two percent of the budget was spent, was consumed very rarely. Salt was also consumed every day and the prisons spent 6.7 percent of their food budget on it. Ecker and Qaim (2008) found that Malawian households spent 39.4 per cent of their food budget on green-leaf vegetables and 15.4 per cent on animal-source foods. Prisons, therefore, spent much less on these food items than did households. This was possibly a pointer to inadequate funding to prisons.

\section{Marshallian (Uncompensated) Price Elasticities of Demand for Food}

Marshallian own-price, cross-price and expenditure elasticities were presented as below.

Own-price elasticities. Table 2 presents Marshallian or uncompensated price elasticities of demand and expenditure or income elasticities of the five foods that were often consumed in Malawi's prisons. The figures in the diagonal of the table are Marshallian own-price elasticities of demand while those on the off-diagonal are Marshallian cross-price elasticities of demand. The figures in the diagonal indicated that the own-price elasticities for the foods usually consumed by prisoners were negative except for vegetables. The own-price elasticity for maize at -0.72 was inelastic. This showed that the demand for maize in prisons was not very sensitive to maize-price changes. Prisons in Malawi strove to acquire the same quantity of maize in-spite of maize-price changes. This was probably a reflection of the fact that maize was a staple food in Malawi.

Table 2. Marshallian (uncompensated) price elasticities of demand for food

\begin{tabular}{ccccccc}
\hline Commodity & Maize & Meat & Beans & Vegetables & Salt & Expenditure Elasticities \\
\hline Maize & -0.72 & -0.02 & -0.11 & -0.35 & 0.20 & 1.01 \\
Meat & -0.79 & -25.92 & 7.97 & -0.12 & 17.60 & 1.25 \\
Beans & -0.21 & 0.46 & -2.10 & 0.98 & -0.21 & 1.08 \\
Vegetables & -3.61 & -0.04 & 7.12 & 0.58 & -4.72 & 0.67 \\
Salt & 1.77 & 5.19 & -0.94 & -3.41 & -3.27 & 0.65 \\
\hline
\end{tabular}

The own-price elasticities for meat, beans and salt were elastic, with meat being the most elastic at -25.92 . The value of elasticity for meat is clearly an outlier, possibly showing that meat is consumed so rarely and it takes up so much money per unit that it is actually an outlier food item in the prisons. These higher values of uncompensated own-price elasticities reflected the greater income effects of a price change in these foods. This meant that a small increase, for example, in the price of meat would force the prisons to drastically reduce meat consumption, practically to zero. This could be the reason why meat was rarely consumed in the prisons. The elasticities of beans and salt at -2.1 and -3.27 respectively, showed that the prisons readily adjusted downwards the quantities of these two foods each time their prices were raised. This would explain the observation that some prisoners made to the effect that they ate watery beans, meaning that there would be just a small number of beans in a plate filled with thin gravy. The high own-price elasticity for salt probably showed that prisons were willing to reduce salt quantities, when faced with an increase in salt prices, in order to channel the money into foods which were more filling, such as, maize. The own-price elasticity for vegetables was positive 0.58 . This showed that, in prisons, vegetables were considered a giffen good. Among less educated people in the Malawi context, vegetables are considered an inferior food. This perception of vegetables may have been applicable in prisons.

Cross-price elasticities. Cross-price elasticities show substitutability and complementarity effects. Positive cross-price elasticities show substitutability while negative cross-price elasticities indicate complementarity. Meat, beans and vegetables were found to be complements to maize. This finding was ordinary and the normal practice in Malawi. Beans were substitutes to meat and vegetables, meaning that prisoners did not eat these foods at the same time. Vegetables, however, complemented meat, although weakly. This was surprising because eating 
meat together with vegetables would suggest luxurious living, of which the prisoners did not have. The possibility here could be that whenever there was meat, there was so little of it that it could ordinarily not be enough for everyone. As a result, vegetables were also prepared so that each prisoner could get a tiny piece of meat, a lot of thin gravy from the meat and some vegetables as fillers.

Salt complemented beans and vegetables, which was ordinary and normal. But salt had a positive relationship with maize and meat, meaning that salt was a substitute to maize as well as meat. This was a strange relationship. But it was earlier deduced that the high own-price elasticity for salt probably showed that prisons were willing to reduce salt quantities, when faced with an increase in salt prices, in order to channel the money into foods which were more filling, such as, maize. In essence, this was a substitution relationship where, in practice, at least in terms of the budget, money for salt was used to procure maize and/or meat because maize was considered a paramount commodity and the maize budget insufficient for the needed maize quantities, while meat was possibly used as a treat to give the prisoners a break from the usual unpalatable food and lift up their spirits.

The prison management may have found it a better evil to sacrifice the salt budget for maize and/or meat, hence the observed substitution effect. But salt substituted meat so strongly that the value of the cross-price elasticity for salt here is clearly an outlier. This relationship possibly indicates two things: firstly, that this substitution relationship occurs so rarely that it is indeed an outlier event. Secondly, that when need arises that the salt budget should be used to procure meat, given the extremely high unit price of meat by prison standards, a substantial portion of the salt budget which is much more than is the case under normal salt usage, is directed towards meat procurement, making such expenditure from the salt budget a real outlier occurrence.

Expenditure elasticities. Expenditure elasticities for maize, meat and beans at 1.01, 1.25 and 1.08 respectively, were just above unity, meaning that these foods were tending towards being luxurious goods. This was a typical reflection of food insecurity. This, however, closely resembled the results obtained by Ecker and Qaim (2008) where they found that expenditure elasticities for maize, animal-source foods and beans among Malawian households were $0.856,1.138$ and 1.026 respectively.

\section{Hicksian (Compensated) Price Elasticities of Demand for Food}

The compensated own-price, cross-price and expenditure elasticities took the same trend and compared well with the Marshallian elasticities given earlier on. Similar to the observation made about uncompensated price elasticities, here too, the negativity property of own-price elasticities held for all foods except vegetables. Therefore, the discussion made earlier on about uncompensated elasticities also applied here. Table 3 shows Hicksian (compensated) price and expenditure elasticities of demand.

Table 3. Hicksian (compensated) price elasticities of demand for food

\begin{tabular}{ccccccc}
\hline & Maize & Meat & Beans & Vegetables & salt & Expenditure elasticities \\
\hline Maize & -0.20 & -0.01 & 0.23 & -0.30 & 0.27 & 1.01 \\
Meat & -0.13 & -25.89 & 8.40 & -0.06 & 17.69 & 1.25 \\
Beans & 0.36 & 0.48 & -1.73 & 1.03 & -0.14 & 1.08 \\
Vegetables & -3.26 & -0.03 & 7.35 & 0.62 & -4.68 & 0.67 \\
Salt & 2.11 & 5.21 & -0.71 & -3.38 & -3.23 & 0.65 \\
\hline
\end{tabular}

\section{Conclusion}

The objective of this study was to determine prison food budget shares and, price and expenditure elasticities of foods commonly eaten in Malawi's prisons. Budget shares for maize and beans were high as reflected by the fact that 86.5 per cent of the prison food budget was spent on these two food items while 6.8 per cent was spent on meat and vegetables. By comparison, it was found that prisons spent much less on meat and vegetables than did households.

Maize was inelastic while meat, beans and salt were elastic with the own-price elasticity for meat being the highest, possibly explaining why meat was rarely eaten in prison. Expenditure elasticities for maize, meat and beans at above unity, meant that these foods were luxuries, which was a typical reflection of a situation of food insecurity. Hicksian own-price, cross-price and expenditure elasticities compared well to Marshallian elasticities. In difficult times, the salt budget was readily sacrificed for maize and meat.

\section{References}

Abdulai, \& Aubert. (2004). A cross-sectional analysis of household demand for food and nutrients in Tanzania. Agricultural Economics, 3(1), 67-79. 
Abdulai, A. (2002). Household demand for food in Switzerland: A quadratic almost ideal demand system. Swiss Journal of Economic Statistics, 138, 1-18.

African Commission on Human and Peoples' Rights. (2002). Prisons in Malawi-Report on a Visit 17 to 28 June 2001 by Dr. V.M. Chirwa Special Rapporteur on Prisons and Conditions of Detention in Africa. Paris, France.

Agresti, A. (1996). An introduction to categorical data analysis. New York: Wiley and Sons Inc. .

Banks, J., Blundell, R., \& Lewbel, A. (1997). Quadratic Engel curves and consumer demand. Review of Economics and Statistics, 124(4), 527-539. https://doi.org/10.1162/003465397557015

Blundell, R. W., \& Robin, J. M. (1999). Estimation in large and disaggregated demand systems: An estimator for conditionally linear systems. Journal of Applied Econometrics, 14, 209-232. https://doi.org/10.1002/(SICI)1099-1255(199905/06)14:3<209::AID-JAE532>3.0.CO;2-X

Blundell, R., Pashardes, P., \& Weber, G. (1993). What do we learn about consumerdemand pattern from micro data? American Economic Review, 83, 570-597.

Bryars, D. (1983). Advanced Level Statistics . Slough : University Tutorial Press.

Deaton, A. S., \& Muellbauer, J. (1980). An Almost Idael Demand System. American Economic Review, 70(3), 359-368.

De Graaff, J. (1985). Introduction to the economics of maize. (Unpublished manuscript).

Dey, M. M. (2000). Analysis of demand for fish in Bangladesh. Aquaculture, Economics and Management, 4, 63-81. https://doi.org/10.1080/13657300009380261

Ecker, O., \& Qaim, M. (2008). Income and price elasticities of food demand and nutrient consumption in Malawi. Orlando: American Agricultural Economics Association.

FAO. (2010). Food Security Information for Decision Making. www.fao.org/docrep/013/am187e/am187e00.pdf.

FAO. (2015). Food Balance Sheets 2015. http://Knoema.com/FAOFBS2015R/food-balance-sheets-2015.

Fisher, D., Fleissig, A. R., \& Serletis, A. (2001). An empirical comparison of flexible demand system functional forms. Journal of Applied Econometrics, 16(1), 59-80. https://doi.org/10.1002/jae.585

Gould, W., \& Villarreal, H. J. (2006). An assessment of the current structure of food demand in Urban China. Agricultural Economics, 34, 1-16. https://doi.org/10.1111/j.1574-0862.2006.00098.x

Government, M. (2006). Malawi Growth and Development Strategy from poverty to prosperity 2006-2011.

Government, M. (2010). Malawi Millenium Development Goals Report.

Huang, J., \& David, C. (1993). Demand for cereal grains in Asia: The effect of urbanization. Agricultural Economics, 8, 107-124. https://doi.org/10.1016/0169-5150(92)90025-T

IFPRI. (2012). Malawi Strategy Support Program, Policy Note 11. Lilongwe: IFPRI.

Kidane, W., Maetz, M., \& Dardel, P. (2006). Food security and agricultural development in Sub-Saharan Africa; building a case for more public support. Rome: FAO.

Kothari, C. (2004). Research Methodology: methods and techniques, 2nd edition . New Delhi: New Age International.

Kumar. (2004). Fish demand and supply projections in India, ICAR-ICLARM Project. New Delhi: Indian Agricultural Research Institute.

Kumar, P., Kumar, A., Parappurathu, S., \& Raju, S. (2011). Estimation of demand elasticity for food commodities in India. Agricultural Economics Research Review, 24, 1-14.

Magnani, R. (1997). Sampling Guide. IMPACT Monitoring Project. Va: Arlington.

Malawi Government. (1983). Laws of Malawi, The Prison Act (Cap. 9:02). Zomba: Malawi Government.

Malawi Government. (1999). Food Security and Nutrition Bulletin. Lilongwe: Ministry of Economic Planning and Development.

Malawi Government. (2005). Food and Nutrition Security Policy. Lilongwe.: Ministry of Agriculture and Food Security.

Malawi Government. (2006). Food Security Policy. Lilongwe: Ministry of Agriculture and Food Security. 
Malawi Government. (2006). Agricultural and livestock development strategy and action plan. Lilongwe: Ministry of Agriculture and Food Security.

Malawi Government. (2006). Malawi Growth and Development Strategy-frompoverty to prosperity 2006-2011.

Malawi Government. (2008). Malawi Population and Housing Census 2008. Zomba: National Statistical Office.

Maxwel, S., \& Frankenberger, T. (1992). Household Food Security: concepts, indicators and measurements; a tecchnical review. New York: UNICEF and IFAD.

McGill, F., McLennan, S., \& Migliorini, J. (2000). Complete Advanced Level Mathematics - Statistics . Cheltenham : Stanley Thornes.

Medecins Sans Frontieres. (2009). No food or medicine here until you die. Retrieved from http://www.doctorswithoutborders.org/publications/article.cfm?id=3433\&cat=special-report.

Meenakshi, J. V., \& Ray, R. (1999). Regional differences in India's food expenditure pattern: A completed demand systems approach . Journal of International Development, 11, 47-74. https://doi.org/10.1002/(SICI)1099-1328(199901/02)11:1<47::AID-JID549>3.0.CO;2-Y

Ministry of Finance, Economic Planning and Development. (2014). Annual Economic Report. Lilongwe: Malawi Government.

Mittal, S. (2010). Application of the QUAIDS model to the food sector in India. Journal of Quantitative Economics, 8(1), 42-54.

Molina, J. S., \& Gil, A. I. (2005). The demand behaviour of consumers in Peru: A demographic analysis using the QUAIDS. Journal of Developing Areas, 39(1), 191-206. https://doi.org/10.1353/jda.2005.0038

Moro, D., \& Sckokai, P. (2000). Heterogenous preferences in household food consumption in Italy. European Review of Agricultural Economics, 27(3), 305-323. https://doi.org/10.1093/erae/27.3.305

Pangaribowo, E., \& Tsegai, D. (2011). Food demand analysis of Indonesian household with particular attention to the poorest. Bonn: Centre for Development Research.

Penal Reform International. (2005). A model for good prison farm management in Africa. Penal Reform in Africa 2000. Retrieved from http://www.panelreform.org/download/prison_farms_eng.pdf

Snyder, C., \& Nicholson, W. (2008). Mcroeconomic Theory- Basic Principles and Extensions. Mason: South-Western Cengage Learning.

Swindale, A., \& Bilinsky, P. (2006). Development of a universally applicable household food insecurity measurement tool: Process, current status and outstanding issues . Journal of Nutrition 136, 1449s-1452s.

Tafere, K., \& Worku, J. (2012). Consumption patterns of livestock products in Ethiopia: Elasticity estimates using HICES (2004/05) Data. IFPRI ESSP II Working Paper 38.

Tefera, N., Demeke, M., \& Rashid, S. (2012). Welfare Impacts of Rising Food Prices in Rural Ethiopia: A Quadratic Almost I deal Demand System Approach. Brazil: IFPRI.

Torero, M., \& Robles, M. (2008). A perfect storm or an opportunity for Latina America: High world commodity prices. IFPRI.

UNDP. (2011). Human Development Report. UNDP.

World Bank. (2008). World Development Report. Washington D.C: World Bank.

Zikmund, W. G. (1997). Business Research Methods, fifth edition. Fort Worth: The Dryden Press.

\section{Copyrights}

Copyright for this article is retained by the author(s), with first publication rights granted to the journal.

This is an open-access article distributed under the terms and conditions of the Creative Commons Attribution license (http://creativecommons.org/licenses/by/3.0/). 